\title{
Morphological assessment of the Zebu Bororo (Wodaabé) cattle of Niger in the West African zebu framework
}

\author{
M. Maaouia A. Moussa ${ }^{1}$, Moumouni Issa ${ }^{1}$, Amadou Traoré ${ }^{2}$, Moustapha Grema ${ }^{1}$, Marichatou Hamani ${ }^{1}$, \\ Iván Fernández ${ }^{3}$, Albert Soudrée ${ }^{4}$ Isabel Álvarez ${ }^{3}$, Moumouni Sanou ${ }^{2}$, Hamidou H. Tamboura ${ }^{2}$, \\ Yenikoye Alhassane ${ }^{1}$, and Félix Goyache ${ }^{3}$ \\ ${ }^{1}$ Université Abdou Moumouni de Niamey, Faculté des sciences et techniques, BP 10960 Niamey, Niger \\ ${ }^{2}$ INERA, Laboratoire de Biologie et santé animals, 04 BP 8645 Ouagadougou 04, Burkina Faso \\ ${ }^{3}$ SERIDA-Deva, Camino de Rioseco 1225, 33394 Deva-Gijón (Asturias), Spain \\ ${ }^{4}$ Université de Koudougou, BP 376 Koudougou, Burkina Faso \\ Correspondence to: Félix Goyache (fgoyache@ @erida.org) and Amadou Traoré (traore_pa@yahoo.fr)
}

Received: 17 May 2017 - Revised: 4 September 2017 - Accepted: 11 September 2017 - Published: 11 October 2017

\begin{abstract}
A total of 357 adult cows and 29 sires belonging to the long-horned Niger Zebu Bororo cattle population were assessed for 13 body measurements and 11 qualitative traits. Data were jointly analysed with 311 cows and 64 sires belonging to other four West African zebu cattle populations, sampled in Burkina Faso and Benin, representative of both the short-horned and the long-horned West African zebu groups using multivariate statistical methods. Besides the other long-horned zebu breed analysed (Zebu Mbororo of Burkina Faso), Zebu Bororo cattle tended to have the highest mean values for all body measurements. Mahalanobis distance matrices further informed that pairs involving Zebu Bororo cattle had the higher differentiation of the dataset. However, contour plots constructed using eigenvalues computed via principal component analysis (PCA) illustrated a lack of differentiation among West African zebu cattle populations at the body measurements level. Correspondence analysis carried out on the 11 qualitative traits recorded allowed for ascertaining a clear differentiation between the Zebu Bororo and the other zebu cattle populations analysed which, in turn, did not show a clear differentiation at the qualitative type traits level. In our data, Zebu Bororo cattle had in high frequency qualitative features such as dropped ears, lyre-shaped horns and red-pied coat colour that are not frequently present in the other West African zebu populations analysed. A directional selection due to a rough consensus of the stock-keepers may be hypothesised. Performance of further analyses to assess the degree in which such breeding differences may be related to genetic or production differences are advised.
\end{abstract}

\section{Introduction}

Although it is accepted that zebu cattle moved and spread into Africa in different historical waves (Payne, 1970; Hanotte et al., 2002) there is archaeological and genetic evidence suggesting that West African zebu cattle is the present-day representative of an ancient introgression of zebu cattle into Africa (Magnavita, 2006; Pérez-Pardal et al., 2010). Together with their historical and genetic importance, West African zebu cattle breeds are a major source of meat, milk and draught power for large human populations. Therefore, their characterisation is the first step for future implementation of effective improvement programmes accounting for their current low levels of productivity (Ibeagha-Awemu and Erhardt, 2006).

Traditionally, West African zebu is classified into two main groups (Rege and Tawah, 1999): the long-horned $\mathrm{Fu}-$ lani zebu cattle and the short-horned Gudali zebu. The long-horned zebu includes two subgroups according to horn shape: the lyre-horned subgroup, with the Gobra and White Fulani cattle as the main representatives, and the long-lyrehorned subgroup consisting of the Red Fulani cattle, which 


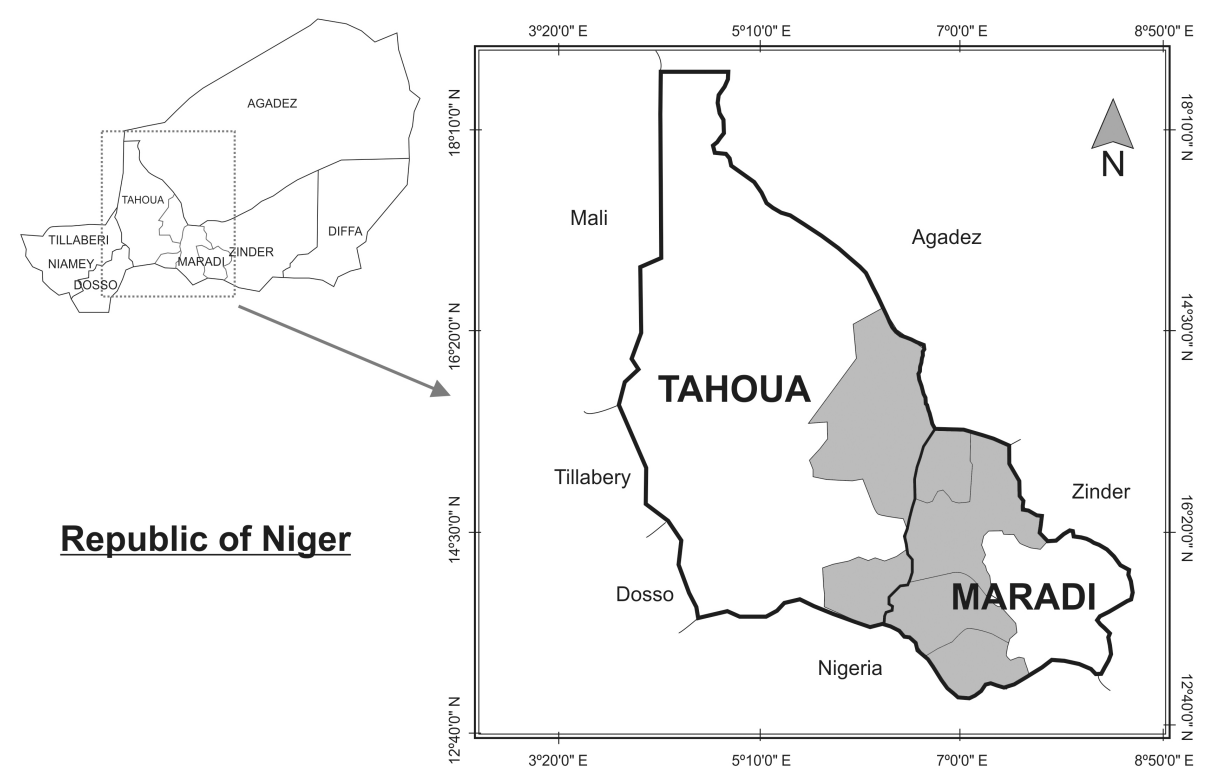

Figure 1. Map (own work of Iván Fernández and Maaouia A. Moussa) illustrating the limits of the provinces of Tahoua and Maradi in the Republic of Niger. Areas in which sampling was carried out are in light grey.

have many local names such as Fellata, Bororo or Mbororo. In any case, definition of breeds within African livestock groups does not follow strict criteria and is usually carried out considering either the geographic areas of spreading or the main ethnic groups acting as stockbreeders (Simon, 1999; Traoré et al., 2008a, b). West African zebu is mainly managed by nomadic stockbreeders such as the Fulani (Peul) people, all across the territory known as the Sahel, the ecoagricultural zone between the Sahara and the coastal rain forests, covering from Sudan in the east to Senegal in the west. Although no selection policies exist and the existence of a strong east-to-west gene flow is accepted (Hanotte et al., 2002), there is consensus on the existence of local populations within West African zebu that can be considered different breeds. Some of them, such as the long-horned Red Bororo (Ibeagha-Awemu and Erhardt, 2006) and White Fulani (Ibeagha-Awemu and Erhardt, 2006; Tawah and Rege, 1996a; Yakubu et al., 2009) or the short-horned zebu Gudali (Tawah and Rege, 1996b), have received some attention to document their main phenotypic and genetic characteristics. However, large morphological and genetic differences among local subpopulations within a breed are likely to exist (Rege and Tawah, 1999), and therefore accumulating information on a different local population is still a challenge in the characterisation of native African livestock.

Recently, nine West African cattle breeds have been jointly analysed for body measurements and qualitative type traits using multifactorial analyses (Traoré et al., 2015, 2016). These analyses included individuals of the Burkina Faso populations of Zebu Azawak (also known as Touareg) and Zebu Mbororo (Red Fulani), as well as the Benin and Burkina Faso populations of the short-horned Zebu Peul. The Zebu
Bororo breed, basically owned by the Wodaabé (Bororo) ethnical group, is included in international databases of farm animal genetic resources together with other long-horned representatives of the West African zebu population. However, the amount of information available on this breed is extremely scant (see as an example the DAGRIS database at http://dagris.ilri.cgiar.org/display.asp?ID=142; Rege et al., 2007).

The aim of the current research was to document the phenotypic variation on body measurements and qualitative type traits in a representative sample of Niger Bororo cattle using the methodology reported in Traoré et al. $(2015,2016)$. Morphological variation was compared with that of four West African zebu cattle populations of Burkina Faso and Benin considering jointly all measured morphological variables using multifactorial techniques to assess within- and betweenpopulations variation.

\section{Materials and methods}

\subsection{Data}

A total of 357 adult cows (age ranging from 4 to 16 years old) and 29 sires (from 4 to 5 years old) belonging to the Niger Zebu Bororo cattle population were assessed for 13 body measurements and 11 qualitative traits. Assessment was carried out in 12 different sites of the provinces of Tahoua (5 sites, 75 cows and 3 sires) and Maradi (7 sites, 282 cows and 26 sires) of the Republic of Niger (Fig. 1). Although the northern parts of these two provinces belong to the Sahara, sampled sites were located within the Sahel area. Sites sampled in the Tahoua province belonged to 
Table 1. Least squares means (in $\mathrm{cm}$ ) and their standard errors (in brackets) for 13 body measurements assessed in cows belonging to five West African zebu cattle breeds. Results and sample size $(N)$ are given per breed. Eigenvectors computed for two factors identified via principal component analysis (eigenvalues $>1$ ) are also given. Eigenvectors higher than $|0.492|$ are in bold. Factor 1 explains $56.43 \%$ of the total variability. Factor 2 explains $9.32 \%$ of the total variability. Different superscripts denote significantly different trait raw means at $p<0.05$. "(BF)" and "(B)" mean Burkina Faso and Benin, respectively.

\begin{tabular}{|c|c|c|c|c|c|c|c|}
\hline & Zebu Bororo & Zebu Azawak & Zebu Mbororo & Zebu Peul (BF) & Zebu Peul (B) & Factor 1 & Factor 2 \\
\hline$N$ & 357 & 29 & 64 & 266 & 128 & & \\
\hline Facial length & $51.0^{\mathrm{b}}(0.3)$ & $50.3^{\mathrm{c}}(0.6)$ & $52.5^{\mathrm{a}}(0.5)$ & $49.3^{\mathrm{c}}(0.4)$ & $43.5^{\mathrm{d}}(0.4)$ & 0.843 & 0.244 \\
\hline Muzzle circumference & $38.6^{\mathrm{a}}(0.3)$ & $37.5^{\mathrm{b}}(0.6)$ & $36.1^{\mathrm{b}, \mathrm{c}}(0.5)$ & $35.9^{\mathrm{c}}(0.3)$ & $37.1^{b}(0.3)$ & 0.358 & 0.668 \\
\hline Horn length & $71.2^{\mathrm{a}}(1.3)$ & $17.7^{\mathrm{e}}(2.4)$ & $50.9^{\mathrm{b}}(1.9)$ & $33.0^{\mathrm{c}}(1.3)$ & $26.9^{\mathrm{d}}(1.3)$ & 0.712 & 0.451 \\
\hline Ear length & $23.8^{\mathrm{a}}(0.3)$ & $18.4^{\mathrm{c}}(0.5)$ & $20.9^{\mathrm{b}}(0.4)$ & $18.7^{\mathrm{c}}(0.3)$ & $15.9^{\mathrm{d}}(0.3)$ & 0.775 & 0.375 \\
\hline Height at withers & $120.5^{\mathrm{a}}(1.0)$ & $115.2^{\mathrm{b}}(1.9)$ & $117.8^{\mathrm{a}}(1.5)$ & $112.6^{\mathrm{b}}(1.0)$ & $101.2^{\mathrm{c}}(1.0)$ & 0.850 & 0.296 \\
\hline Heart girth & $156.7^{\mathrm{a}}(1.3)$ & $145.9^{\mathrm{b}, \mathrm{c}}(2.4)$ & $148.0^{\mathrm{b}}(1.9)$ & $142.9^{\mathrm{c}}(1.3)$ & $133.7^{\mathrm{d}}(1.3)$ & 0.754 & 0.464 \\
\hline Height at hips & $127.0^{\mathrm{a}}(1.0)$ & $122.5^{\mathrm{b}}(2.0)$ & $125.8^{\mathrm{a}}(1.5)$ & $119.9^{\mathrm{b}}(1.1)$ & $105.7^{\mathrm{c}}(1.1)$ & 0.885 & 0.257 \\
\hline Body length & $134.8^{\mathrm{a}}(1.1)$ & $126.3^{\mathrm{b}}(2.0)$ & $131.8^{\mathrm{a}}(1.6)$ & $126.8^{\mathrm{b}}(1.1)$ & $118.7^{\mathrm{c}}(1.1)$ & 0.817 & 0.233 \\
\hline Thorax depth & $67.1^{\mathrm{a}}(0.8)$ & $55.1^{\mathrm{c}}(1.4)$ & $57.0^{\mathrm{b}}(1.1)$ & $53.3^{\mathrm{c}, \mathrm{d}}(0.8)$ & $52.1^{\mathrm{d}}(0.8)$ & 0.702 & 0.324 \\
\hline Shoulder width & $23.9^{\mathrm{a}}(0.3)$ & $21.4^{\mathrm{c}}(0.6)$ & $22.5^{\mathrm{b}}(0.5)$ & $21.7^{\mathrm{c}, \mathrm{d}}(0.4)$ & $19.0^{\mathrm{d}}(0.4)$ & 0.227 & 0.677 \\
\hline Pelvic width & $43.3^{\mathrm{a}}(0.4)$ & $31.6^{\mathrm{b}, \mathrm{c}}(0.8)$ & $32.6^{\mathrm{b}}(0.6)$ & $30.6^{\mathrm{c}}(0.4)$ & $31.9^{\mathrm{b}, \mathrm{c}}(0.4)$ & 0.479 & 0.678 \\
\hline Ischium width & $14.0^{\mathrm{a}}(0.3)$ & $13.1^{\mathrm{b}}(0.5)$ & $13.6^{\mathrm{a}}(0.4)$ & $12.9^{\mathrm{b}}(0.3)$ & $14.3^{\mathrm{a}}(0.3)$ & 0.188 & 0.659 \\
\hline Rump length & $36.3^{\mathrm{c}}(1.1)$ & $41.0^{\mathrm{a}, \mathrm{b}}(2.1)$ & $42.9^{\mathrm{a}}(1.6)$ & $40.3^{\mathrm{a}, \mathrm{b}}(1.1)$ & $38.7^{\mathrm{b}, \mathrm{c}}(1.1)$ & 0.070 & 0.036 \\
\hline
\end{tabular}

Table 2. Least squares means (in $\mathrm{cm}$ ) and their standard errors (in brackets) for 13 body measurements assessed in sires belonging to five West African zebu cattle breeds. Results and sample size $(N)$ are given per breed. Eigenvectors computed for two factors identified via principal component analysis (eigenvalues $>1$ ) are also given. Eigenvectors higher than $|0.510|$ are in bold. Factor 1 explains $61.88 \%$ of the total variability. Factor 2 explains $8.21 \%$ of the total variability. Different superscripts denote significantly different trait raw means at $p<0.05$. "(BF)" and "(B)" mean Burkina Faso and Benin, respectively.

\begin{tabular}{|c|c|c|c|c|c|c|c|}
\hline & Zebu Bororo & Zebu Azawak & Zebu Mbororo & Zebu Peul (BF) & Zebu Peul (B) & Factor 1 & Factor 2 \\
\hline$N$ & 29 & 8 & 14 & 24 & 17 & & \\
\hline Facial length & $53.6^{\mathrm{a}}(1.0)$ & $51.5^{\mathrm{b}}(1.7)$ & $52.9^{\mathrm{a}, \mathrm{b}}(1.4)$ & $50.8^{\mathrm{b}}(1.1)$ & $42.6^{\mathrm{c}}(1.0)$ & 0.764 & 0.568 \\
\hline Muzzle circumference & $41.3^{\mathrm{a}}(1.3)$ & $39.1^{\mathrm{b}}(2.0)$ & $38.7^{\mathrm{b}}(1.7)$ & $39.2^{\mathrm{a}, \mathrm{b}}(1.4)$ & $37.3^{\mathrm{b}}(1.2)$ & 0.612 & 0.324 \\
\hline Horn length & $65.9^{\mathrm{a}}(3.5)$ & $12.0^{\mathrm{d}}(5.6)$ & $46.1^{\mathrm{b}}(4.6)$ & $27.6^{\mathrm{c}}(3.8)$ & $24.4^{\mathrm{c}}(3.2)$ & 0.867 & 0.033 \\
\hline Ear length & $24.6^{\mathrm{a}}(0.7)$ & $20.4^{\mathrm{c}}(1.2)$ & $22.3^{\mathrm{b}}(1.0)$ & $20.3^{\mathrm{b}, \mathrm{c}}(0.8)$ & $15.6^{\mathrm{d}}(0.7)$ & 0.845 & 0.270 \\
\hline Height at withers & $128.4^{\mathrm{a}}(3.1)$ & $124.2^{\mathrm{a}}(5.0)$ & $125.6^{\mathrm{a}}(4.1)$ & $121.5^{\mathrm{a}}(3.4)$ & $101.3^{\mathrm{b}}(2.9)$ & 0.708 & 0.603 \\
\hline Heart girth & $160.3^{\mathrm{a}}(4.5)$ & $155.4^{\mathrm{a}, \mathrm{b}}(7.2)$ & $149.4^{\mathrm{b}}(5.9)$ & $151.6^{\mathrm{a}, \mathrm{b}}(4.9)$ & $128.5^{\mathrm{c}}(4.1)$ & 0.731 & 0.483 \\
\hline Height at hips & $136.4^{\mathrm{a}}(3.2)$ & $131.5^{\mathrm{a}, \mathrm{b}}(5.1)$ & $136.2^{\mathrm{a}, \mathrm{b}}(4.1)$ & $128.4^{\mathrm{b}}(3.4)$ & $105.8^{\mathrm{c}}(2.9)$ & 0.703 & 0.615 \\
\hline Body length & $138.1^{\mathrm{a}}(3.2)$ & $137.0^{\mathrm{a}, \mathrm{b}}(5.1)$ & $131.2^{\mathrm{b}}(4.2)$ & $132.2^{\mathrm{b}}(3.5)$ & $115.5^{\mathrm{c}}(2.9)$ & 0.737 & 0.503 \\
\hline Thorax depth & $62.2^{\mathrm{a}}(2.5)$ & $57.4^{\mathrm{b}}(4.0)$ & $58.8^{\mathrm{b}}(3.3)$ & $56.8^{\mathrm{b}}(2.8)$ & $51.3^{\mathrm{b}}(2.3)$ & 0.705 & 0.307 \\
\hline Shoulder width & $25.0^{\mathrm{a}}(1.7)$ & $25.8^{\mathrm{a}}(2.6)$ & $22.9^{\mathrm{a}, \mathrm{b}}(2.2)$ & $23.9^{\mathrm{a}}(1.8)$ & $18.5^{\mathrm{b}}(1.5)$ & 0.525 & 0.154 \\
\hline Pelvic width & $43.2^{\mathrm{a}}(1.4)$ & $31.1^{\mathrm{b}}(2.3)$ & $29.3^{\mathrm{b}}(1.8)$ & $31.5^{\mathrm{b}}(1.5)$ & $30.9^{\mathrm{b}}(1.3)$ & 0.831 & -0.057 \\
\hline Ischium width & $13.2^{\mathrm{a}}(1.3)$ & $12.6^{\mathrm{a}}(2.0)$ & $12.9^{\mathrm{a}}(1.7)$ & $14.0^{\mathrm{a}}(1.4)$ & $13.4^{\mathrm{a}}(1.2)$ & 0.104 & 0.143 \\
\hline Rump length & $36.6^{\mathrm{a}, \mathrm{b}}(1.3)$ & $41.0^{\mathrm{a}, \mathrm{b}}(2.1)$ & $42.1^{\mathrm{a}}(1.7)$ & $40.7^{\mathrm{a}, \mathrm{b}}(1.4)$ & $36.5^{\mathrm{b}}(1.2)$ & 0.035 & 0.867 \\
\hline
\end{tabular}

the municipalities of Boundou $\left(14^{\circ} 50^{\prime} \mathrm{N}, 6^{\circ} 56^{\prime} \mathrm{E}\right)$, Goulbi $\left(13^{\circ} 27^{\prime} \mathrm{N}, 7^{\circ} 02^{\prime} \mathrm{E}\right)$, Bangui $\left(13^{\circ} 40^{\prime} \mathrm{N}, 06^{\circ} 16^{\prime} \mathrm{E}\right)$ and Djangangari $\left(14^{\circ} 55^{\prime} \mathrm{N}, 06^{\circ} 34^{\prime} \mathrm{E}\right)$ while sites sampled in the Maradi province belonged to the municipalities of Chigrenne $\left(15^{\circ} 03^{\prime} \mathrm{N}, 06^{\circ} 36^{\prime} \mathrm{E}\right)$, Bermo $\left(15^{\circ} 16^{\prime} \mathrm{N}, 06^{\circ} 44^{\prime} \mathrm{E}\right)$ and Birni Lalley $\left(14^{\circ} 26^{\prime} \mathrm{N}, 06^{\circ} 45^{\prime} \mathrm{E}\right)$. Each sampling location was georeferenced using GPS Garmin-50 devices (Garmin Ltd., Olathe, KS, USA). Assessments were carried out in 2015, during the rainy season (August-September).
The original dataset included records of 21 quantitative traits. However, only 15 of them coincided with those obtained by Traoré et al. $(2015,2016)$ in nine West African cattle populations. Moreover, definition of two of the traits recorded (tail length and facial width) differed between the current research and the project of Traoré et al. $(2015,2016)$. Therefore, after editing, only 13 quantitative traits were used for analyses (Tables 1 and 2): facial length (from orbital fossa to upper lip), muzzle circumference, horn length (greater curvature), ear length, height at withers, heart girth, height at 
hips (tuber coxae), body length (from lateral tuberosity of the humerus to tuber ischii), thorax depth, shoulder width (between lateral tuberosities of the humerus), pelvic width (between tuber ischii), ischium width (between tuber ischii) and rump length (from tuber coxae to tuber ischii).

Eleven qualitative traits were scored with the same withintrait levels, codes and definitions used in Traoré et al. (2015, 2016): cephalic profile, ear shape, muzzle pigmentation, eyelid pigmentation, hoof pigmentation, horn colour, dewlap size, backline profile, horn shape, spotting pattern and coat colour pattern (Table 3 ).

Age of the individuals was approximated by examining dentition and direct enquiries to owners. For statistical purposes, the age of the individuals was grouped as follows: 4 years old (5 cows and 6 sires), from 5 to 10 years old (252 cows and 23 sires) and older than 10 years (100 cows). Body measurements were carried out, with the animals standing stationary on a flat floor, using Lydthin stick, tape measure and Vernier caliper. No ethics statement was required for data collection. Body measurements and trait scores were obtained from different technicians visiting farms with the permission of the owners. Animals were managed by the owners.

Data were jointly analysed with 375 individuals belonging to the 4 West African zebu cattle populations previously analysed by Traoré et al. (2015, 2016): Zebu Azawak (29 cows and 8 sires), Zebu Mbororo (64 cows and 14 sires), Zebu Peul of Burkina Faso (266 cows and 24 sires) and Zebu Peul of Benin (128 cows and 17 sires). Zebu Mbororo of Burkina Faso and Zebu Bororo of Niger can be considered local representatives of the long-horned West African zebu cattle group (Rege and Tawah, 1999). However, in the current analysis both samples were considered as belonging to different populations. Consequently, the name given by Traoré et al. $(2015,2016)$ to the long-horned zebu of Burkina Faso (Zebu Mbororo) was used throughout the text to point out the different geographical origin of data. For consistency, Zebu Peul of Burkina Faso and Benin were treated as belonging to different populations. Traoré et al. $(2015,2016)$ did not find clear differentiation at the qualitative traits level among West African zebu populations. Therefore, when necessary for descriptive purposes, frequencies of qualitative traits were pooled for West African zebu cattle other than Zebu Bororo.

\subsection{Statistical analyses}

Body traits were analysed separately for cows and sires to avoid bias due to sexual dimorphism (see Traoré et al., 2016, for a review on this issue). Preliminary analyses showed that neither country of origin (Benin, Burkina Faso and Niger) nor type of West African zebu (long-horned: Zebu Bororo and Zebu Mbororo; short-horned: Zebu Peul and Zebu Azawak) had statistically significant influence on data. Therefore, a very simple model, including the effect of the breed
Table 3. Between-breeds Mahalanobis distance matrices computed within sex using 13 body measurements. The distance matrix computed on the cows' dataset are below diagonal. The distance values corresponding to the sires' dataset are above diagonal. All distance pairs are statistically significant for $p<0.0001$. "(BF)" and “(B)" mean Burkina Faso and Benin, respectively.

\begin{tabular}{lrrrrc}
\hline & $\begin{array}{c}\text { Zebu } \\
\text { Bororo }\end{array}$ & $\begin{array}{r}\text { Zebu } \\
\text { Azawak }\end{array}$ & $\begin{array}{r}\text { Zebu } \\
\text { Mbororo }\end{array}$ & $\begin{array}{r}\text { Zebu } \\
\text { Peul } \\
(\mathrm{BF})\end{array}$ & $\begin{array}{r}\text { Zebu } \\
\text { Peul } \\
(\mathrm{B})\end{array}$ \\
\hline Zebu Bororo & & 47.49 & 22.48 & 29.66 & 30.62 \\
Zebu Azawak & 41.65 & & 12.74 & 3.83 & 21.37 \\
Zebu Mbororo & 20.12 & 11.22 & & 4.83 & 17.69 \\
Zebu Peul (BF) & 27.26 & 4.05 & 2.89 & & 10.98 \\
Zebu Peul (B) & 28.23 & 18.05 & 19.57 & 12.33 & \\
\hline
\end{tabular}

(five levels) and the age of the individual (three levels for cows and two levels for sires), was fitted using PROC GLM of the SAS/STAT ${ }^{\mathrm{TM}}$ package (SAS Institute Inc., Cary, NC) to estimate least squares means, and their corresponding standard errors, for each level of the breed effect. Additionally, Duncan's multiple-range test was performed on the breed effect means. Furthermore, the between-breeds Mahalanobis distance matrix was computed on body measurements using the CANDISC procedure of SAS/STAT.

Relationships among body measurements were summarised via principal component analysis (PCA), using the PROC FACTOR of SAS/STAT, to determine the number of independent traits that account for most of the phenotypic variation in body measurements. This analysis was computed from the correlation matrix among measurements to ensure that all traits were treated as equally important, giving the same weight to the variables regardless their own variance. A VARIMAX rotation was applied to the retained components in order to obtain factor pattern coefficients considerably less correlated than the original body measurements. Only factors accounting for more variation than any individual type trait (eigenvalue $>1$ ) were retained.

Frequencies of each level of the qualitative traits analysed were computed using the PROC FREQ of SAS/STAT ${ }^{\mathrm{TM}}$. Statistical significance of the differences in the frequencies observed among the Zebu Bororo breed and the other West African zebu cattle was assessed pooling both sexes via chisquared Mantel-Haenszel test. Relationships between qualitative traits were assessed via correspondence analysis using the PROC CORRESP of SAS/STAT ${ }^{\mathrm{TM}}$. Two canonical dimensions and their eigenvectors were computed to account for association between the levels of the traits scored. Following Parés-Casanova and Jordana (1999) and Grema et al. (2017) each score of the qualitative traits assessed was consider arbitrarily as polymorphism of the trait and used to compute the between-breeds Reynolds distance matrix using the program MolKin (Gutiérrez et al., 2005). Statistical con- 
fidence on the distance values was assessed via bootstrapping using 1000 replicates.

Eigenvectors computed for each individual via PCA and correspondence analyses were used to construct contour plots illustrating $75 \%$ confidence region (per breed) of the relationships among individuals using the library ggplot2 of R (http://CRAN.R-project.org/). Eigenvectors computed for each individual via PCA were regressed on latitude (in decimal format) of the sampling site using the Proc REG of SAS/STAT to assess variation related to geography.

\section{Results}

\subsection{Continuous traits}

Least-squares means for the body measurements assessed by breed are given in Table 1 (cows) and Table 2 (sires). Data corresponding to the Zebu Azawak, Zebu Mbororo and Zebu Peul populations were previously analysed in Traoré et al. (2015, 2016). However, least-squares estimates may vary due to differences in both the datasets analysed (including the split of Zebu Peul into two different geographical populations) and the models fitted for analyses. For both males and females, Zebu Bororo cattle tended to have the higher estimates of the dataset and the Zebu Peul of Benin the lower. In any case, differences in estimates for body measurements between Zebu Bororo and the other long-horned zebu population analysed (Zebu Mbororo) were low. Even in the case of facial length, Zebu Bororo cows had lower estimates than Zebu Mbororo (51.0 \pm 0.3 vs. $52.5 \pm 0.5$, respectively). Furthermore, these two breeds had very similar values for key traits such as height at hips and ischium width for both cows and sires. Actually, the higher differences between the Niger Zebu Bororo and the Burkina Faso Zebu Mbororo populations were assessed in measurement traits such as ear length and horn length closely related with key qualitative features such as ear shape and horn shape.

Both in males and in females, PCA identified two factors with eigenvalues higher than 1 . In the females dataset factor 1 (eigenvalue $=7.34$ ) accounted for $56.43 \%$ of the total variation and factor 2 (eigenvalue $=1.21$ ) explained $9.32 \%$. In the sires dataset factor 1 (eigenvalue $=8.04$ ) accounted for $61.88 \%$ of the total variation and factor 2 (eigenvalue $=1.07$ ) explained $8.21 \%$. In females (Table 1 ) factor 1 clearly summarised the general size of the individuals (height and length) while factor 2 summarised the body width. In sires (Table 2), with a relatively limited sample size, factor 2 was less informative on body trait variation. The eigenvalues computed via PCA for each individual were plotted in a two-dimensional space to illustrate the between-breeds relationships for body measurements (Fig. 2). No differentiation among West African zebu populations was found. The $75 \%$ confidence regions computed for Zebu Bororo, Zebu Azawak, Zebu Mbororo, Zebu Peul of Burkina Faso and Zebu Peul of Benin were intermingled, particularly in the case of
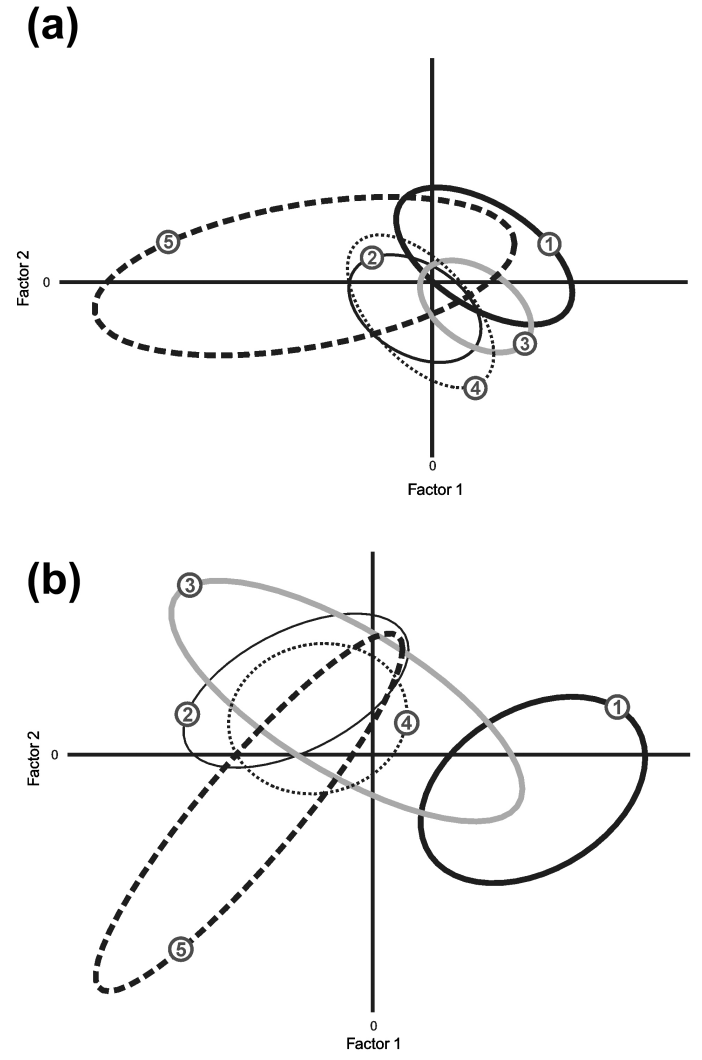

Figure 2. Contour plots summarising, per breed, the information provided by the 13 body traits analysed via principal component analysis. Contours show the $75 \%$ confidence region of the withinbreed relationships among individuals. Factor 1 is on the $x$ axis and factor 2 on the $y$ axis. Panel (a) corresponds to the female subset and (b) corresponds to the sires subset. Numbers on contours mean the following: (1) Zebu Bororo; (2) Zebu Azawak; (3) Zebu Mbororo; (4:) Zebu Peul of Burkina Faso; and (5) Zebu Peul of Benin.

females in which sample size was not a limitation (Fig. 2a). The eigenvalues computed for each individual corresponding to the factor 1 identified either the cows' or sires' dataset were also regressed on latitude to ascertain the existence of a geographical pattern of variation on body measurements in West African zebu cattle. Both in females $\left(R^{2}=0.598\right)$ and in males $\left(R^{2}=0.370\right)$ positive and significant regression coefficients were computed $(0.34467$ in cows and 0.24049 in sires) showing that overall body size increased with latitude).

The between-breeds Mahalanobis distance matrix is given in Table 3. All pairwise distances were statistically significant $(p<0.001)$. The hypothesis that the breeds' means are equal in the populations analysed was also tested using Wilks' lambda. This parameter took a significant value $(p<0.0001)$ for both the cows $(\lambda=0.04662812 ; F=75.37$; degrees of freedom $=52)$ and the sires $(\lambda=0.02895334$; $F=8.64$; degrees of freedom $=52$ ) datasets. Therefore, differences found were statistically different from zero. For both sires and cows, the largest distances were found between the 
Zebu Bororo cattle and the other breeds. In both sexes the higher differentiation was found for the pair Zebu BororoZebu Azawak (41.65 for cows and 47.49 for sires). Zebu Bororo had the lowest differentiation with Zebu Mbororo.

\subsection{Qualitative traits}

The frequencies (in percentage) of each level of the 11 qualitative traits recorded for Zebu Bororo cows and sires are given in Table 4. Data corresponding to the Zebu Azawak, Zebu Mbororo, Zebu Peul of Burkina Faso and Zebu Peul of Benin populations were pooled with no sex separation to be used as a reference for Zebu Bororo. A chi-squared Mantel-Haenszel test showed that incidence of all the analysed traits varied significantly between Zebu Bororo cows and sires and the other West African zebu cattle for $p<0.001$ except for cephalic profile and backline profile (Table 4). For these two traits zebu cattle were majority straight, regardless of the population to which the individuals belonged. However, Zebu Bororo cattle had large differences for most qualitative traits with the other West African zebu cattle. The "most frequent" Zebu Bororo individuals had dropped ears, non-pigmented muzzle, grey-coloured lyre-shaped horns and red-pied coat colour pattern. This general appearance substantially departs from that of the other West African zebu cattle populations analysed in which horizontal ears and pigmented muzzle are the rule and it is possible to find a high variation in horn shape and coat colour (Table 4).

A correspondence analysis was carried out on the 11 qualitative traits recorded. Two correspondence dimensions identified accounted for 36.77 and $21.60 \%$, respectively, in the cows' dataset and 32.43 and $26.57 \%$ of the total variation, respectively, in the sires' dataset. The solutions provided for each individual by the correspondence analysis were plotted in a two-dimensional space. Figure 3 shows that the $75 \%$ confidence region computed for the Zebu Bororo breed is clearly separated from those of the other zebu populations at both the cows and the sires level which. In turn, the nonNiger West African zebu populations showed highly intermingled $75 \%$ confidence regions.

Between-breeds Reynolds' distance matrices were computed for each sex to quantify differentiation due to qualitative type traits (Table 5). The pairs involving Zebu Bororo cattle had the higher distance values.

\section{Discussion}

Although analyses focusing on body measurements are relatively frequent in East African zebu (Mwacharo et al., 2006), zoometric studies on West African zebu cattle were scant before Traoré et al. (2015, 2016). Many times, zoometrical studies cannot be compared straightforwardly due to differences in both the definition of the traits assessed and the heterogeneity of the samples used. Hall (1991) using 10 Sokoto Gudali and 29 White Fulani humped Nigerian cattle re-

\section{(a)}
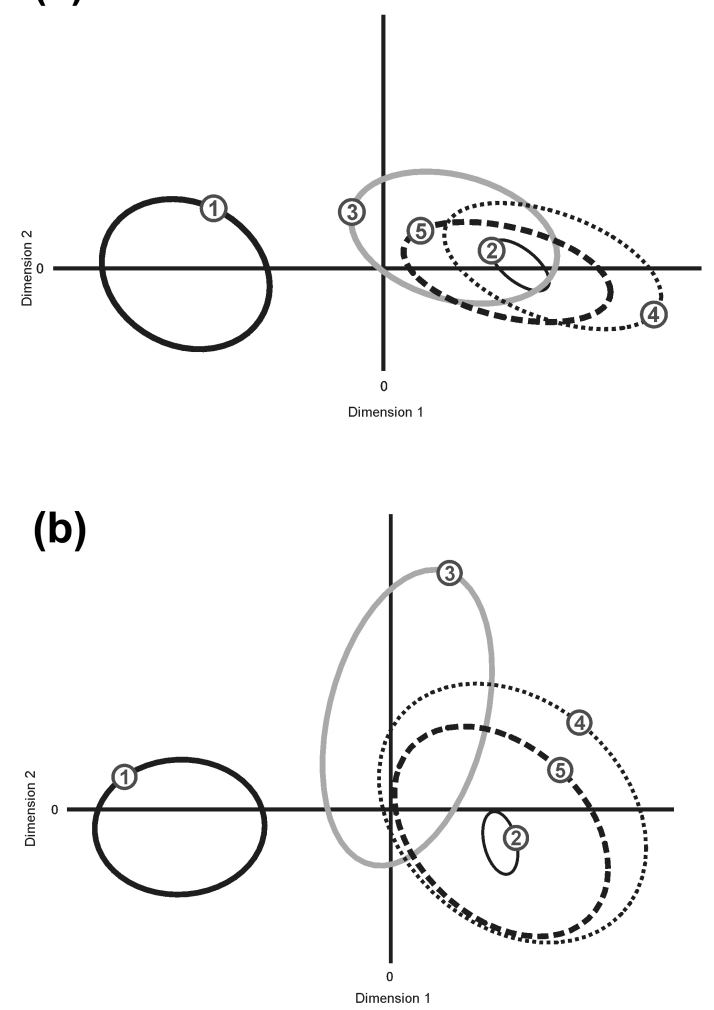

Figure 3. Contour plots summarising, per breed, the information provided by the 11 qualitative traits analysed via correspondence analyses. Contours show the $75 \%$ confidence region of the within-breed relationships among individuals. Correspondence dimension 1 is on the $x$ axis and correspondence dimension 2 on the $y$ axis. Panel (a) corresponds to the female subset and (b) corresponds to the sires subset. Numbers on contours mean the following: (1) Zebu Bororo; (2) Zebu Azawak; (3) Zebu Mbororo; (4) Zebu Peul of Burkina Faso; and (5) Zebu Peul of Benin.

ported mean values for body length and height at withers of $123.6 \pm 2.3$ and $130.9 \pm 2.5 \mathrm{~cm}$, respectively, for the former and $117.1 \pm 0.9$ and $121.4 \pm 1.0 \mathrm{~cm}$, respectively, for the latter. Although many of the traits analysed were not consistent with the measurements carried out in the current research, Yakubu et al. (2009), using 79 male and 125 female individuals of Nigerian White Fulani cattle with age ranging from 1.5 to 3.6 years, reported mean values for Height at Withers of $101.11 \pm 2.19 \mathrm{~cm}$ in males and $100.48 \pm 2.70 \mathrm{~cm}$ in females.

Local populations belonging to the long-horned West African zebu cattle group are expected to show large morphological differences. However, the current research confirms that West African zebu is a basically unstructured population at the body measurements level. Differences of the means of the traits assessed due to the breed or population are relatively poor (Tables 1 and 2) and when body traits are considered as a whole it is not possible to distinguish 
Table 4. Frequencies (in percentage) of each level of the 11 qualitative traits assessed in Zebu Bororo sires and cows. Additionally, frequencies observed in four other West African zebu populations, comprising a total of 311 cows and 64 sires, for the same traits are given as a reference.

\begin{tabular}{|c|c|c|c|c|c|}
\hline \multirow[b]{2}{*}{ Trait } & \multicolumn{2}{|r|}{ Class } & \multicolumn{2}{|c|}{ Zebu Bororo } & \multirow{2}{*}{$\begin{array}{l}\text { Other } \\
\text { Wes } \\
\text { African } \\
\text { Zebu* }\end{array}$} \\
\hline & Code & Definition & Sires & Cows & \\
\hline$N$ & & & 29 & 357 & 375 \\
\hline \multirow[t]{3}{*}{ Cephalic profile ${ }^{\mathrm{ns}}$} & 1 & concave & & 1.7 & 1.8 \\
\hline & 2 & convex & 10.3 & 6.2 & 5.7 \\
\hline & 3 & straight & 89.7 & 92.2 & 92.5 \\
\hline \multirow[t]{3}{*}{ Ear shape } & 1 & horizontal & 10.3 & 6.2 & 99.8 \\
\hline & 2 & drop & 89.7 & 92.2 & 0.2 \\
\hline & 3 & upright & & 1.6 & \\
\hline \multirow[t]{2}{*}{ Muzzle pigmentation } & 1 & pigmented & 24.1 & 6.2 & 70.9 \\
\hline & 2 & not pigmented & 75.9 & 93.8 & 29.1 \\
\hline \multirow[t]{2}{*}{ Eyelid pigmentation } & 1 & pigmented & 100.0 & 95.5 & 70.5 \\
\hline & 2 & not pigmented & & 4.5 & 29.5 \\
\hline \multirow[t]{2}{*}{ Hoof pigmentation } & 1 & pigmented & 100.0 & 91.6 & 86.5 \\
\hline & 2 & not pigmented & & 8.4 & 13.5 \\
\hline \multirow[t]{4}{*}{ Horn colour } & 1 & black & 6.9 & 1.4 & 14.1 \\
\hline & 2 & grey & 89.7 & 92.4 & 5.7 \\
\hline & 3 & brown & 3.5 & 6.2 & 51.6 \\
\hline & 4 & two coloured & & & 28.7 \\
\hline \multirow[t]{3}{*}{ Dewlap size } & 1 & well developed & 44.8 & 22.1 & 14.0 \\
\hline & 2 & poorly developed & 55.2 & 74.2 & 50.6 \\
\hline & 3 & small & & 3.6 & 35.4 \\
\hline \multirow[t]{3}{*}{ Backline profile ${ }^{\mathrm{ns}}$} & 1 & straight & 96.6 & 94.7 & 95.9 \\
\hline & 2 & concave & & 2.5 & 1.2 \\
\hline & 3 & convex & 3.5 & 2.8 & 2.8 \\
\hline \multirow[t]{6}{*}{ Horn shape } & 1 & cup & 6.9 & 0.8 & 16.0 \\
\hline & 2 & crescent & & 2.2 & 40.0 \\
\hline & 3 & lyre & 93.1 & 95.8 & 30.6 \\
\hline & 4 & wheel & & & 1.3 \\
\hline & 5 & crown & & 1.1 & 11.7 \\
\hline & 7 & en arrière & & & 0.4 \\
\hline \multirow[t]{3}{*}{ Spotting pattern } & 1 & absence & 82.8 & 81.2 & 53.8 \\
\hline & 2 & pied & 17.2 & 13.2 & 15.1 \\
\hline & 3 & spotted & & 5.6 & 31.1 \\
\hline \multirow[t]{13}{*}{ Coat colour pattern } & 1 & black & 34.5 & 3.4 & 4.6 \\
\hline & 2 & black-pied & & & 20.7 \\
\hline & 3 & white & & 0.3 & 10.8 \\
\hline & 4 & red & & 0.8 & 1.5 \\
\hline & 5 & red-pied & 58.6 & 91.0 & 9.5 \\
\hline & 6 & roan & 6.9 & 1.4 & 1.4 \\
\hline & 7 & fawn & & 2.5 & 1.0 \\
\hline & 8 & diluted fawn & & & 10.9 \\
\hline & 9 & grey & & 0.3 & 9.4 \\
\hline & 10 & blond & & & 0.3 \\
\hline & 11 & fawn-blond & & & 14.9 \\
\hline & 12 & dun-red & & 0.3 & 8.3 \\
\hline & 13 & fawn-red & & & 6.9 \\
\hline
\end{tabular}

* Includes individuals belonging to the Zebu Azawak, Zebu Mbororo and Zebu Peul breeds sampled in Burkina Faso and Benin. "ns" as superscript means that frequencies observed for each level of these traits among Bororo cattle and other West African zebu did not depart from random expectation at $p<0.05$. 
Table 5. Between-breeds Reynolds' distance matrices computed within sex using the individual scores of 11 qualitative type traits. The distance matrix computed on the cows' dataset are below diagonal. The distance values corresponding to the sires' dataset are above diagonal. Standard deviations of the estimates of the Reynolds' distance pairs (in brackets) were computed via bootstrapping using 1000 replicates.

\begin{tabular}{lccccc}
\hline & Zebu Bororo & Zebu Azawak & Zebu Mbororo & Zebu Peul (BF) & Zebu Peul (B) \\
\hline Zebu Bororo & & $0.482(0.062)$ & $0.331(0.048)$ & $0.373(0.04)$ & $0.370(0.049)$ \\
Zebu Azawak & $0.239(0.016)$ & & $0.324(0.067)$ & $0.121(0.026)$ & $0.219(0.043)$ \\
Zebu Mbororo & $0.253(0.015)$ & $0.152(0.024)$ & & $0.159(0.039)$ & $0.198(0.049)$ \\
Zebu Peul (BF) & $0.424(0.016)$ & $0.035(0.004)$ & $0.069(0.010)$ & & $0.103(0.026)$ \\
Zebu Peul (B) & $0.391(0.019)$ & $0.081(0.010)$ & $0.099(0.017)$ & $0.057(0.006)$ & \\
\hline
\end{tabular}

West African zebu populations straightforwardly (Fig. 2). Although the two long-horned zebu analysed (Bororo and Mbororo) tended to have higher values on body traits (Tables 1 and 2) the inclusion of the effect of the type of West African zebu did not allow a better fit of the model to data. Traoré et al. (2015), using taurine, zebu and sanga individuals, identified a geographical cline in body measurements in West African cattle with a continuous decrease in size southwards. This is consistent with the increase in size with latitude assessed here using West African zebu only. Zebu Peul sampled in Benin tended to have the lower mean values in body traits (Tables 1 and 2) but also the larger $75 \%$ confidence intervals (Fig. 2) suggesting this cattle can be a transition population between West African zebu and sanga (taurine $\times$ zebu crosses) cattle.

At the qualitative traits level, Zebu Bororo cattle showed significant differentiation from the other West African zebu populations analysed. Zebu Bororo had qualitative type features such as dropped ears, lyre-shaped horns and red-pied coat colour that are not present in high frequency in the other West African zebu populations. Furthermore, the non-Niger West African zebu analysed had larger within-populations variability for these key qualitative traits than Zebu Bororo (Traoré et al., 2015, 2016). Other West African zebu breeds, such as White Fulani (Tawah and Rege, 1996a), are known to have virtually fixed qualitative type traits such as coat colour. However, this may not be the rule in African cattle in which no selection programmes exist. In such scenario, it is usually difficult to differentiate between cattle breeds according to qualitative traits due to the existence of a very high withinbreed variation due to local preferences of the stock keepers (Desta et al., 2011).

The differentiation found in Zebu Bororo may be a consequence of a directional selection due to a rough consensus of the stock-keepers. At the neutral molecular level it is well known that livestock differentiation in West Africa is more likely due to geographic distance rather than to a breed differences or to different expected origins of the livestock populations (Ibeagha-Awemu and Erhardt, 2006; Traoré et al., 2012; Álvarez et al., 2014). Further genetic analyses are advised to assess the degree of uniqueness of Zebu Bororo in the West African zebu framework.
In summary, the current research confirmed that West African zebu cattle can be considered a single large population at the zoometric level. However, there may exist between-subpopulations differentiation at the qualitative type traits level. The results presented may support the implementation of future work lines aiming at the ascertainment of possible relationships between such differences, related to breeding, and genetic or production differences.

Data availability. Data used in this research were generated through project CORAF/WECARD World Bank no. 03/GRN/16 and West African Agricultural Productivity Programme (WAAPP/Niger). Data can be made available on request after obtaining the permission of all researchers involved in these projects.

Competing interests. The authors declare that they have no conflict of interest.

Acknowledgements. The authors are grateful for the financial support provided by West African Agricultural Productivity Programme (WAAPP/Niger). The authors are indebted to the breeders involved in this study for their kind collaboration. This study made use of data generated through CORAF/WECARDWorld Bank no. 03/GRN/16. Félix Goyache, Iván Fernández and Isabel Álvarez are supported by grant FICYT GRUPIN14-113 and MICIIN-FEDER AGL2016-77813-R. CompGen.

Edited by: Steffen Maak

Reviewed by: two anonymous referees 


\section{References}

Álvarez, I., Traoré, A., Fernández, I., Lecomte, T., Soudré, A., Kaboré, A., Tamboura, H. H., and Goyache, F.: Assessing introgression of Sahelian zebu genes into native Bos taurus breeds in Burkina Faso, Mol. Biol. Rep., 41, 3745-3754, https://doi.org/10.1007/s11033-014-3239-x, 2014.

Desta, T. T., Ayalew, W., and Hedge, B. P.: Breed and trait preferences of Sheko cattle keeper in southern Ethiopia, Trop. Anim. Health Prod., 43, 851-856, https://doi.org/10.1007/s11250-0109772-2, 2011.

Grema, M., Traoré, A., Issa, M., Hamani, M., Abdou, M., Fernández, I., Soudré, A., Álvarez, I., Sanou, M., Tamboura, H. H., Alhassane, Y., and Goyache, F.: Morphological assessment of Niger Kuri cattle using multivariate methods, S. Afr. J. Anim. Sci., 47, 505-515, https://doi.org/10.4314/sajas.v47i1, 2017.

Gutiérrez, J. P., Royo, L. J., Álvarez, I., and Goyache, F.: MolKin v2.0: a computer program for genetic analysis of populations using molecular coancestry information, J. Hered., 96, 718-721, https://doi.org/10.1093/jhered/esi118, 2005.

Hall, S. J. G.: Body dimensions of Nigerian cattle, sheep and goats, Anim. Prod., 53, 61-69, https://doi.org/10.1017/S0003356100005985, 1991.

Hanotte, O., Bradley, D. G., Ochieng, J. W., Verjee, Y., Hill, E. W., and Rege, J. E.: African pastoralism: genetic imprints of origins and migrations, Science, 296, 336-339, https://doi.org/10.1126/science.1069878, 2002.

Ibeagha-Awemu, E. M. and Erhardt G.: An evaluation of genetic diversity indices of the Red Bororo and White Fulani cattle breeds with different molecular markers and their implications for current and future improvement options, Trop. Anim. Health Prod., 38, 431-441, https://doi.org/10.1007/s11250-006-4347-y, 2006.

Magnavita C.: Ancient Humped Cattle in Africa: A View from the Chad Basin, Afr. Archaeol. Rev., 23, 55-84, https://doi.org/10.1007/s10437-006-9008-z, 2006.

Mwacharo, J. M., Okeyo, A. M., Kamande, G. K., and Rege, J. E. O.: The small East African shorthorn zebu cows in Kenya. I: Linear body measurements, Trop. Anim. Health Prod, 38, 65-74, https://doi.org/10.1007/s11250-006-4266-y, 2006.

Parés-Casanova, P. M. and Jordana, J.: Relaciones genéticas entre razas ibéricas de caballos utilizando caracteres morfológicos (prototipos raciales), Anim. Genet. Resour. Inf., 26, 75-94, https://doi.org/10.1017/S1014233900001218, 1999.

Payne, W. J. A.: Cattle production in the tropics, 1st Edn., Longman, London, 1970.

Pérez-Pardal, L., Royo, L. J., Beja-Pereira, A., Chen, S., Cantet, R. J. C., Traoré, A., Curik, I., Sölkner, J., Bozzi, R., Fernández, I., Álvarez, I., Gutiérrez, J. P., Gómez, E., Ponce de Leon, F. A., and Goyache, F.: Multiple paternal origins of domestic cattle revealed by Y-specific interspersed multilocus microsatellites, Heredity, 105, 511-519, https://doi.org/10.1038/hdy.2010.30, 2010.
Rege, J. E. O. and Tawah, C. L.: The state of African cattle genetic resources II. Geographical distribution, characteristics and uses of present-day breeds and strains, Anim. Genet. Resour. Inf., 26, 1-26, https://doi.org/10.1017/S1014233900001152, 1999.

Rege, J. E. O., Hanotte, O., Mamo, Y., Asrat, B., and Dessie, T.: Domestic Animal Genetic Resources Information System (DAGRIS), International Livestock Research Institute, Addis Ababa, Ethiopia, http://dagris.ilri.cgiar.org (last access: 27 February 2017), 2007.

Simon, D. L.: European approaches to conservation of farm animal genetic resources, Anim. Genet. Resour. Inf., 25, 79-99, https://doi.org/10.1017/S1014233900005794, 1999.

Tawah, C. L. and Rege, J. E. O.; White Fulani cattle of West and Central Africa, Anim. Genet. Resour. Inf., 17, 137-158, https://doi.org/10.1017/S101423390000064X, 1996a.

Tawah, C. L. and Rege, J. E. O.: Gudali cattle of West and Central Africa, Anim. Genet. Resour. Inf., 17, 159-170, https://doi.org/10.1017/S1014233900000651, 1996b.

Traoré, A., Tamboura, H. H., Kabore, A., Royo, L. J., Fernández, I., Álvarez, I., Sangare, M., Bouchel, D., Poivey, J. P., Francois, D., Toguyeni, A., Sawadogo, L., and Goyache, F.: Multivariate characterization of morphological traits in Burkina Faso sheep, Small Rum. Res., 80, 62-67, https://doi.org/10.1016/j.smallrumres.2008.09.011, 2008a.

Traoré, A., Tamboura, H. H., Kabore, A., Royo, L. J., Fernández, I., Álvarez, I., Sangare, M., Bouchel, D., Poivey, J. P., Sawadogo, L., and Goyache, F.: Multivariate analyses on morphological traits of goats in Burkina Faso, Arch. Anim. Breed., 51, 588600, 2008b.

Traoré, A., Álvarez, I., Fernández, I., Pérez-Pardal, L., Kaboré, A., Ouédraogo-Sanou, G. M. S., Zaré, Y., Tamboura, H. H., and Goyache, F.: Ascertaining gene flow patterns in livestock populations of developing countries: a case study in Burkina Faso goat, BMC Genetics, 13, 35, https://doi.org/10.1186/1471-215613-35, 2012.

Traoré, A., Koudandé, D. O., Fernández, I., Soudré, A., Álvarez, I., Diarra, S., Diarra, F., Kaboré, A., Sanou, M., Tamboura, H. H., and Goyache, F.: Geographical assessment of body measurements and qualitative type traits in West African cattle, Anim. Health Prod., 47, 1505-1513, https://doi.org/10.1007/s11250015-0891-7, 2015.

Traoré, A., Koudandé, D. O., Fernández, I., Soudré, A., Álvarez, I., Diarra, S., Diarra, F., Kaboré, A., Sanou, M., Tamboura, H. H., and Goyache, F.: Multivariate characterization of morphological traits in West African cattle sires, Arch. Anim. Breed., 59, 337344, https://doi.org/10.5194/aab-59-337-2016, 2016.

Yakubu, A., Ogah, D. M., and Idahor, K. O.: Principal component analysis of the morphostructural indices of White Fulani cattle, Trakia J. Sci., 7, 67-73, 2009. 